\title{
MESENTERIC MICROCIRCULATORY DYSFUNCTIONS AND TRANSLOCATION OF INDIGENOUS BACTERIA IN A RAT MODEL OF STRANGULATED SMALL BOWEL OBSTRUCTION
}

\author{
Fernando Luiz Zanoni, ${ }^{I}$ Simon Benabou, ${ }^{\mathrm{I}}$ Karin Vicente Greco, ${ }^{\mathrm{I}}$ Ana Carolina \\ Ramos Moreno, ${ }^{\mathrm{III}}$ José Walber Miranda Costa Cruz, ${ }^{\mathrm{I}}$ Fernando Paranaiba \\ Filgueira, ${ }_{\text {IV }}$ Marina Baquerizo Martinez, ${ }^{\text {III }}$ Luiz Francisco Poli de Figueiredo, ${ }^{\text {I }}$ \\ Maurício Rocha e Silva, ${ }^{\mathrm{I}}$ Paulina Sannomiya ${ }^{\mathrm{I}}$
}

doi: $10.1590 / \mathbf{S 1 8 0 7 - 5 9 3 2 2 0 0 9 0 0 0 9 0 0 0 1 3}$

Zanoni FL, Benabou S, Greco KV, Moreno ACR, Costa Cruz JWM, Filgueira FP. Mesenteric microcirculatory dysfunctions and translocation of indigenous bacteria in a rat model of strangulated small bowel obstruction. Clinics. 2009;64(9):911-9.

PRUPOSE: Bacterial translocation has been shown to occur in critically ill patients after extensive trauma, shock, sepsis, or thermal injury. The present study investigates mesenteric microcirculatory dysfunctions, the bacterial translocation phenomenon, and hemodynamic/metabolic disturbances in a rat model of intestinal obstruction and ischemia.

METHODS: Anesthetized (pentobarbital $50 \mathrm{mg} / \mathrm{kg}$, i.p.) male Wistar rats (250-350 g) were submitted to intestinal obstruction or laparotomy without intestinal obstruction (Sham) and were evaluated 24 hours later. Bacterial translocation was assessed by bacterial culture of the mesenteric lymph nodes (MLN), liver, spleen, and blood. Leukocyte-endothelial interactions in the mesenteric microcirculation were assessed by intravital microscopy, and P-selectin and intercellular adhesion molecule (ICAM)-1 expressions were quantified by immunohistochemistry. Hematocrit, blood gases, lactate, glucose, white blood cells, serum urea, creatinine, bilirubin, and hepatic enzymes were measured.

RESULTS: About $86 \%$ of intestinal obstruction rats presented positive cultures for $E$. coli in samples of the mesenteric lymph nodes, liver, and spleen, and 57\% had positive hemocultures. In comparison to the Sham rats, intestinal obstruction induced neutrophilia and increased the number of rolling ( 2-fold), adherent ( 5-fold), and migrated leukocytes $(\sim 11$-fold); this increase was accompanied by an increased expression of P-selectin ( 2-fold) and intercellular adhesion molecule-1 ( 2-fold) in the mesenteric microcirculation. Intestinal obstruction rats exhibited decreased $\mathrm{PaCO}$, alkalosis, hyperlactatemia, and hyperglycemia, and increased blood potassium, hepatic enzyme activity, serum urea, creatinine, and bilirubin. A high mortality rate was observed after intestinal obstruction ( $83 \%$ at $72 \mathrm{~h} v$ s. $0 \%$ in Sham rats).

CONCLUSION: Intestinal obstruction and ischemia in rats is a relevant model for the in vivo study of mesenteric microcirculatory dysfunction and the occurrence of bacterial translocation. This model parallels the events implicated in multiple organ dysfunction (MOD) and death.

KEYWORDS: Mesenteric microcirculation; Bacterial translocation; Intestinal obstruction; Leukocyte-endothelium interactions; Adhesion molecules.

\footnotetext{
${ }^{\text {I }}$ Heart Institute (InCor), LIM 11, University of São Paulo Medical School - São Paulo/SP, Brazil.

II The William Harvey Research Institute, St. Bartholomew's and The Royal London School of Medicine - London, UK.

III Department of Clinical Analysis, Faculty of Pharmaceutical Sciences, University of São Paulo - São Paulo/SP, Brazil.

${ }^{\text {IV }}$ Department of Pharmacology, Institute of Biomedical Sciences, University of São Paulo - São Paulo/SP, Brazil.

Email: zanoni@usp.br

Tel: 55113061.7178

Received for publication on April 30, 2009

Accepted for publication on June 11, 2009
}

\section{INTRODUCTION}

Since Berg and Garlington ${ }^{1}$ observed the presence of indigenous intestinal bacteria in the mesenteric lymph nodes of mice and the term "bacterial translocation" was created, several studies have supported the hypothesis of the "gut origin of sepsis." This hypothesis states that bacteria that normally inhabit the intestinal lumen cross the epithelial barrier and act as a source of sepsis in distant places. ${ }^{2,3}$ The 
concept of bacterial translocation (BT) leading to systemic sepsis has been supported by several experimental studies ${ }^{4-8}$ and some clinical studies, ${ }^{9-12}$ such as when the host is immunocompromised or critically ill. Conditions associated with splanchnic hypoperfusion, such as hemorrhagic shock and intestinal ischemia, result in the gut becoming a cytokine-generating organ, which is followed by intestinal mucosal injury and loss of gut-barrier function..$^{13,14}$

The present study investigates microcirculatory alterations and bacterial translocation in a rat model of intestinal obstruction and ischemia, as well as the metabolic, hemodynamic, and inflammatory responses associated with sepsis and MOD development.

\section{MATERIALS AND METHODS}

\section{Animal Model}

The experimental protocols were approved by the Animal Subject Committee of the Heart Institute (InCor) of the Faculdade de Medicina da Universidade de São Paulo. All experiments adhered to the ethical principles in animal research adopted by the Brazilian College of Animal Experimentation. Male Wistar rats about 2 months of age that weighed 250-350 $\mathrm{g}$ at the beginning of the experiments were used. The animals were maintained at $23^{\circ} \mathrm{C} \pm 2^{\circ} \mathrm{C}$ under a cycle of $12 \mathrm{~h}$ light/12 $\mathrm{h}$ darkness and allowed access to food and water ad libitum. The animals were randomized into the Sham group, in which animals were subjected only to laparotomy and the ileum was manipulated but not ligated, and the Intestinal obstruction and ischemia $(I O)$ group, in which (after the induction of anesthesia) the animals were subjected to intestinal obstruction and ligature of mesenteric vessels.

\section{Anesthesia and Monitoring}

Rats were anesthetized with intraperitoneal sodium pentobarbital $(50 \mathrm{mg} / \mathrm{kg})$. The carotid artery and jugular vein were cannulated with a polyethylene (PE-10) catheter to monitor arterial pressure and collect blood samples.

\section{Operative Technique}

Under anesthesia and in aseptic conditions (shaved skin, sterile operative fields, and use of povidone-iodine), a median laparotomy $(3 \mathrm{~cm}$ midline ventral abdominal skin incision and a similar incision in the abdominal muscles) was carried out. The cecum was exposed, and the ileum was ligated at $1.5 \mathrm{~cm}$ proximal to the ileocecal valve, followed by ligation of the mesenteric vessels that supply $7-10 \mathrm{~cm}$ of the ileal loop. The midline incision was closed in 2 layers with a 4-0 suture (Ethicon, Somerville, NJ, USA). After the surgical procedures, the animals were kept warm at $37^{\circ} \mathrm{C}$ for $1 \mathrm{~h}$ and returned to their cages.

\section{Hematocrit, Blood Gases, and Blood Lactate}

Hematocrit, blood gases, and blood lactate analyses were performed on blood samples obtained from the carotid artery at baseline $(0 \mathrm{~h})$ and $24 \mathrm{~h}$ after intestinal obstruction and ischemia. Hematocrit was measured by microcapillary tube centrifugation. Arterial blood gases and lactate were analyzed by a gas analyzer (Radiometer ABL 555, Radiometer Medical, Copenhagen, Denmark).

\section{White Blood Cell Counts and Blood Glucose Levels}

White blood cell counts and blood glucose levels (Advantage glucose monitor, Lilly, São Paulo, SP) were measured in blood samples obtained from the cut tip of the tail at baseline $(0 \mathrm{~h})$ and $24 \mathrm{~h}$ after the surgical procedures. Total cell counts were determined using a hemocytometer. Differential cell counts were carried out on stained films under oil immersion microscopy. A total of 100 cells were counted and classified on the basis of normal morphological criteria.

\section{Serum Biochemistry}

Twenty-four hours after the surgical procedures, blood was collected from the abdominal aorta for analysis of urea, creatinine, bilirubin, and the activities of the enzymes alanine aminotransferase (ALT), alkaline phosphatase, aspartate aminotransferase (AST), alkaline phosphatase (ALP), and lactic dehydrogenase (LDH); all of these were measured using commercially available kits (Modular Analytics, Roche Diagnostics GmbH, Mannheim, Germany).

\section{Microbiological Assay}

Samples of mesenteric lymph nodes (MLN), liver, spleen, and blood from the abdominal aorta were obtained $24 \mathrm{~h}$ after the surgical procedures. The tissues were macerated and diluted with $1.0 \mathrm{~mL}(6.0 \mathrm{~mL}$ for liver $) \mathrm{NaCl}$ $0.9 \%$. Aliquots of $100 \mu \mathrm{L}$ were sown on Mac Conkey agar (Difco) and incubated for $24 \mathrm{~h}$ at $37^{\circ} \mathrm{C}$. Blood samples $(1 \mathrm{~mL})$ were inoculated into Hemocult ${ }^{\circledR} \mathrm{I}$ (Laborclin, PR, Brazil) under sterile conditions for 24 to $48 \mathrm{~h}$ at $37^{\circ} \mathrm{C}$. Samples were then sown on Mac Conkey agar and incubated for $24 \mathrm{~h}$ at $37^{\circ} \mathrm{C}$. 


\section{Intravital Microscopy of the Mesenteric Microcircula- tion}

Intravital microscopy of the mesenteric microcirculation was performed as previously described. ${ }^{16,17}$ In brief, the animals were anesthetized with intraperitoneal sodium pentobarbital $(50 \mathrm{mg} / \mathrm{kg})$. After an abdominal midline incision, the distal ileum and its accompanying mesentery were exposed for in vivo microscopic examination of the microcirculation. The animals were maintained on a specially designed stage warmed by circulating water kept at $37^{\circ} \mathrm{C}$. The stage had a transparent platform on which the tissue to be transilluminated was placed. The mesentery was continuously perfused throughout the study period with a warmed $\left(37^{\circ} \mathrm{C}\right) \mathrm{Krebs}-H e n s e l e i t$ solution (113 $\mathrm{mmol} / \mathrm{L} \mathrm{NaCl}, 4.7 \mathrm{mmol} / \mathrm{L} \mathrm{KCl}, 2.5 \mathrm{mmol} / \mathrm{L} \mathrm{CaCl}_{2} \cdot 2 \mathrm{H}_{2} \mathrm{O}$, $25 \mathrm{mmol} / \mathrm{L} \mathrm{NaHCO}_{3}, 1.1 \mathrm{mmol} / \mathrm{L} \mathrm{MgSO}_{4}, 1.1 \mathrm{mmol} / \mathrm{L}$ $\mathrm{KH}_{2} \mathrm{PO}_{4}, 5 \mathrm{mmol} / \mathrm{L}$ glucose, $\mathrm{pH}$ 7.20-7.40) that was saturated with a mixture of gases $\left(95 \% \mathrm{~N}_{2}\right.$ and $\left.5 \% \mathrm{CO}_{2}\right)$. This procedure kept the microcirculatory characteristics unchanged throughout the intravital microscopic analysis. The mesenteric microcirculation was assessed after 10 min of stabilization. Three to five postcapillary venules (diameter 15-25 $\mu \mathrm{m}$ ) were selected for each animal. A charge-coupled device color camera (TK-C1380U, JVC Co, Tokyo, Japan) was incorporated into a triocular microscope (Axioplan 2, Carl Zeiss Co, MünchenHallbergmoos, Germany) to facilitate the observation of the enlarged image $(425 \mathrm{x})$ on a microcomputer monitor (SyncMaster 753DFX, Samsung, Manaus, Brazil). Analyses of leukocyte-endothelium interactions were performed online using image-computer software (Axiovision 4.1, Carl Zeiss Co) with an incorporated modulus of interactive measurements and time laps. Images were stored, enabling off-line playback analysis. Rolling leukocytes were defined as white blood cells that moved at a significantly slower velocity than the erythrocytes in a given microvessel. ${ }^{18}$ The number of rolling leukocytes was presented as the mean number of cells passing at a designated line perpendicular to the venular axis per 10 min. A given section of the vascular bed was tested only once. Three to five microvessels were selected in a single animal to avoid sampling variability. Individual leukocyte rolling velocity was calculated using the time required for steady rolling leukocytes to travel a defined distance in the microvessel. ${ }^{19}$ Rolling velocity in each vessel was calculated as the average velocity of 10 leukocytes. Results are presented in micrometers per second. A leukocyte was considered to be adherent to the venular endothelium if it remained stationary for more than $30 \mathrm{~s} .{ }^{18,20}$ Adherent cells were counted during a $10 \mathrm{~min}$ period in a $100 \mu \mathrm{m}$ segment of the vessel. The number of leukocytes accumulating in the connective tissue adjacent to the chosen postcapillary venule was measured in a standard area of $5,000 \mu \mathrm{m}^{2}$. Two to three different fields were evaluated for each microvessel, and three to five microvessels were selected for a single animal.

\section{Immunohistochemistry for Adhesion Molecules}

Twenty-four hours after their surgical procedures, the animals were anesthetized with intraperitoneal sodium pentobarbital $(50 \mathrm{mg} / \mathrm{kg}$ ) and exsanguinated by abdominal aorta puncture. The mesentery was removed, immersed in hexane, and frozen in liquid nitrogen. Serial $8 \mu \mathrm{m}$ cryostat sections were placed onto glass slides previously coated with organosilane (Sigma Chemical Co, St. Louis, MO, USA). For the immunodetection of intercellular adhesion molecule (ICAM)-1 and P-selectin on the mesenteric microvessels, samples were fixed in acetone and exposed to $3 \%$ hydrogen peroxide. SuperBlock buffer (Pierce Biotechnology, Rockford, IL, USA) was used to block nonspecific sites. Tissue sections were incubated overnight at $4^{\circ} \mathrm{C}$ with a biotin-conjugated mouse monoclonal antibody anti-rat ICAM-1 (CD54) (Seikagaku Co, Tokyo, Japan) that was diluted 1:100 in phosphate buffered saline (PBS) containing $0.3 \%$ Tween 20. After washing the slides with PBS, sections were incubated with streptoavidin (R \& D Systems Inc, Minneapolis, MN, USA) that was diluted 1:500 in PBS for $1 \mathrm{~h}$ at room temperature, developed with 3.3'-diaminobenzidine (DAB) (Sigma Chemical Co, St Louis, MO, USA), and counterstained with hematoxylin. A biotin-conjugated mouse monoclonal antibody anti-human P-selectin (R\&D Systems Inc, Minneapolis, MN, USA) diluted 1:100 in PBS was used for the immunodetection of P-selectin on mesenteric microvessels. After fixation in acetone, tissue samples were incubated overnight with the antibody at $4^{\circ} \mathrm{C}$ and rinsed in PBS. The samples were then treated with streptoavidin at room temperature for $1 \mathrm{~h}$, developed with DAB, and counterstained with hematoxylin. Analyses were performed with Image-Pro Plus, version 4.1 (Media Cybernetics, Silver Spring, Md). Results are presented as mean optical density.

\section{Statistical Analysis}

Data are presented as means \pm SEM and analyzed by Student's $t$ test. The incidence of BT was evaluated by Chi-square analysis, and quantification of colony formation units/g tissue was evaluated by Mann-Whitney test. $P$ values less than 0.05 were considered significant. 
Table 1 - Analysis of arterial blood gases, lactate, hematocrit, electrolytes and glucose levels

\begin{tabular}{|c|c|c|c|c|}
\hline \multirow[t]{2}{*}{ Groups } & \multicolumn{2}{|c|}{ Sham } & \multicolumn{2}{|c|}{ IO } \\
\hline & Baseline & $24 \mathrm{~h}$ & Baseline & $24 \mathrm{~h}$ \\
\hline $\mathrm{PaO}_{2}(\mathrm{mmHg})$ & $77 \pm 2$ & $69 \pm 3$ & $92 \pm 2$ & $91 \pm 14$ \\
\hline $\mathrm{PaCO}_{2}(\mathrm{mmHg})$ & $48 \pm 1$ & $45 \pm 1$ & $44 \pm 0$ & $34 \pm 7 *$ \\
\hline $\mathrm{SO}_{2}(\%)$ & $94 \pm 1$ & $93 \pm 1$ & $97 \pm 0$ & $95 \pm 3$ \\
\hline $\mathrm{pH}$ & $7.35 \pm 0.01$ & $7.40 \pm 0.01$ & $7.36 \pm 0.01$ & $7.49 \pm 0.05^{*}$ \\
\hline $\mathrm{HCO}_{3}^{-}(\mathrm{mmol} / \mathrm{L})$ & $25.9 \pm 0.8$ & $27.0 \pm 0.4$ & $24.1 \pm 0.3$ & $24.4 \pm 2.9$ \\
\hline Lactate $(\mathrm{mmol} / \mathrm{L})$ & $2.4 \pm 0.2$ & $2.4 \pm 0.2$ & $2.3 \pm 0.2$ & $4.8 \pm 0.3^{\S}$ \\
\hline Hematocrit (\%) & $43 \pm 1$ & $40 \pm 1$ & $42 \pm 1$ & $45 \pm 2$ \\
\hline Sodium $(\mathrm{mmol} / \mathrm{L})$ & $137 \pm 5$ & $143 \pm 1$ & $139 \pm 3$ & $136 \pm 4$ \\
\hline Potassium (mmol/L) & $4.0 \pm 0.2$ & $3.6 \pm 0.2$ & $4.5 \pm 0.3$ & $5.0 \pm 0.3^{*}$ \\
\hline Glucose (mg/dL) & $91 \pm 4$ & $96 \pm 3$ & $96 \pm 2$ & $196 \pm 15^{\S}$ \\
\hline
\end{tabular}

IO, intestinal obstruction and ischemia; Sham, laparotomy without IO. Data are presented as mean \pm SEM for 5 to 7 animals.

$* P<0.05 ;{ }^{\S} P<0.001$ vs. corresponding value in Sham group

\section{RESULTS}

\section{Clinic and Hemodynamic}

Both Sham and IO rats presented a reduction in body weight $24 \mathrm{~h}$ after the surgical procedures. Loss of weight was greater in the IO group $(-18 \pm 1 \mathrm{~g} v s .-7 \pm 1 \mathrm{~g}$ in Sham, $P<0.001)$. There were no differences in mean arterial pressure between the groups 120 min after surgery (115 \pm 3 $\mathrm{mmHg}$ in Sham vs. $113 \pm 4 \mathrm{mmHg}$ in IO, $P>0.05$ ). Total blood leukocyte counts were similar in the Sham and IO rats at baseline $\left(13,571 \pm 730\right.$ cells $/ \mathrm{mm}^{3}$ in Sham $v s$. $13,050 \pm 1,238$ cells $/ \mathrm{mm}^{3}$ in IO, $\left.P>0.05\right)$ and $24 \mathrm{~h}$ after surgery $\left(12,201 \pm 1,223\right.$ cells $/ \mathrm{mm}^{3}$ in Sham vs. $16,614 \pm 1,997$ cells $/ \mathrm{mm}^{3}$ in IO, $\left.P>0.05\right)$. Neutrophil/lymphocyte ratios were similar in both groups at baseline $(0.33 \pm 0.04$ in Sham vs. $0.32 \pm 0.03$ in IO, $P>0.05$ ) but increased in the IO group at $24 \mathrm{~h}(4.30 \pm 0.54$ vs. $0.18 \pm 0.01$ in Sham, $P<0.001)$. In the IO group $(\mathrm{n}=12), 58 \%$ of the animals died at $48 \mathrm{~h}$ and $83 \%$ at $72 \mathrm{~h}$ after surgery, whereas no animal in the Sham group $(\mathrm{n}=12)$ died within the same period $(P<0.001)$.

\section{Arterial Blood Gases, Lactate, Hematocrit, Electro- lytes, and Glucose Levels}

All animals presented similar arterial oxygenation 24 $\mathrm{h}$ after surgery, as depicted by the values for $\mathrm{PaO}_{2}$ and $\mathrm{SO}_{2}$ in Table 1. Relative to blood gases and $\mathrm{pH}$ levels, the IO rats presented decreased $\mathrm{PaCO}_{2}$ and alkalosis. However, $\mathrm{HCO}_{3}^{-}$levels did not change. No differences were observed in hematocrit and sodium concentration. Blood potassium was increased in the IO group $24 \mathrm{~h}$ after surgery $(P<0.05)$. The IO rats also showed significant increases compared to
Sham rats in blood lactate and blood glucose levels $24 \mathrm{~h}$ after surgery $(P<0.001)$.

\section{Serum Biochemistry}

Twenty-four hours after intestinal obstruction and ischemia, the serum activity of AST and ALP and the levels of creatinine, urea, and total bilirubin were significantly increased in the IO group compared to the Sham group $(P<$ 0.05). Results are shown in Table 2.

Table 2 - Serum biochemistry

\begin{tabular}{lcc}
\hline & Sham & IO \\
\hline Urea (mg/dL) & $44.0 \pm 1.7$ & $111.0 \pm 26.2^{*}$ \\
Creatinine (mg/dL) & $0.25 \pm 0.02$ & $0.63 \pm 0.09^{\S}$ \\
ALT (IU/L) & $43 \pm 6$ & $84 \pm 17$ \\
AST (IU/L) & $124 \pm 8$ & $302 \pm 71^{*}$ \\
ALP (IU/L) & $130 \pm 7$ & $274 \pm 78^{\S}$ \\
LDH (IU/L) & $1,904 \pm 395$ & $3,067 \pm 908$ \\
Bilirubin (mg/dL) & & \\
$\quad$ Indirect & $0.10 \pm 0.00$ & $0.26 \pm 0.06^{*}$ \\
$\quad$ Direct & $0.10 \pm 0.00$ & $0.06 \pm 0.02$ \\
Total & $0.20 \pm 0.00$ & $0.30 \pm 0.06$ \\
\hline
\end{tabular}

IO, intestinal obstruction and ischemia; Sham, laparotomy without IO; ALT, alanine aminotransferase; AST, aspartate aminotransferase; ALP, alkaline phosphatase; LDH, lactate dehydrogenase. Data are presented as mean \pm SEM for 5 animals in each group

${ }^{*} P<0.05$ and ${ }^{\S} P<0.01$ vs. Sham group

\section{Microbiological Assays}

The results, summarized in Table 3, showed that samples 
Table 3 - Microbiological assays

\begin{tabular}{|c|c|c|c|c|c|c|c|}
\hline \multirow[t]{2}{*}{ Group } & \multicolumn{2}{|c|}{ MLN } & \multicolumn{2}{|c|}{ Liver } & \multicolumn{2}{|c|}{ Spleen } & \multirow{2}{*}{$\frac{\text { Blood }}{+/ \mathrm{n}}$} \\
\hline & $+/ \mathrm{n}$ & $\mathrm{CFU} / \mathrm{g}$ & $+/ \mathrm{n}$ & $\mathrm{CFU} / \mathrm{g}$ & $+/ \mathrm{n}$ & $\mathrm{CFU} / \mathrm{g}$ & \\
\hline Sham & $1 / 7$ & 57 & $0 / 7$ & NG & $0 / 7$ & NG & $0 / 7$ \\
\hline IO & $6 / 7 *$ & $2,939 \pm 1,751^{\S}$ & $6 / 7^{\S}$ & $953 \pm 525^{\S}$ & $6 / 7{ }^{\S}$ & $4,616 \pm 1,973^{s}$ & $4 / 7$ \\
\hline
\end{tabular}

$\mathrm{IO}$, intestinal obstruction and ischemia; Sham, laparotomy without $\mathrm{IO} ;+\mathrm{n}$, number of animals with positive cultures for $E$. coli / total number of animals; $\mathrm{CFU} / \mathrm{g}$, colony formation units /g tissue (mean value $\pm \mathrm{SEM}, \mathrm{n}=7$ animals in each group); NG, no growth.

${ }^{*} P<0.05$ and ${ }^{\S} P<0.01 \mathrm{vs}$. Sham group

of MLN, liver, and spleen were positive for the presence of E. coli in $86 \%$ of the IO rats, and $57 \%$ of these animals had positive hemoculture for $E$. coli. The presence of $E$. coli was observed in a sample of MLN from one Sham rat only.

\section{Leukocyte-Endothelial Interactions}

For observation of mesenteric microcirculation, single and unbranched postcapillary venules were selected; their diameters ranged from 15 to $25 \mu \mathrm{m}$ in all groups. Rolling leukocyte velocity and the number of rolling, adherent, and migrated leukocytes are presented in Figure 2. Twentyfour hours after surgery, rolling velocity was lower in IO rats $(\sim 13 \mu \mathrm{m} / \mathrm{s})$ than in Sham rats $(\sim 18 \mu \mathrm{m} / \mathrm{s}, P<0.001)$. Relative to Sham-operated rats, which exhibited $131 \pm 4$ rolling cells $/ 10 \mathrm{~min}, 3 \pm 0$ adherent cells $/ 100 \mu \mathrm{m}$ venule length, and $1 \pm 0$ migrated cells $/ 5,000 \mu \mathrm{m}^{2}$, IO rats presented
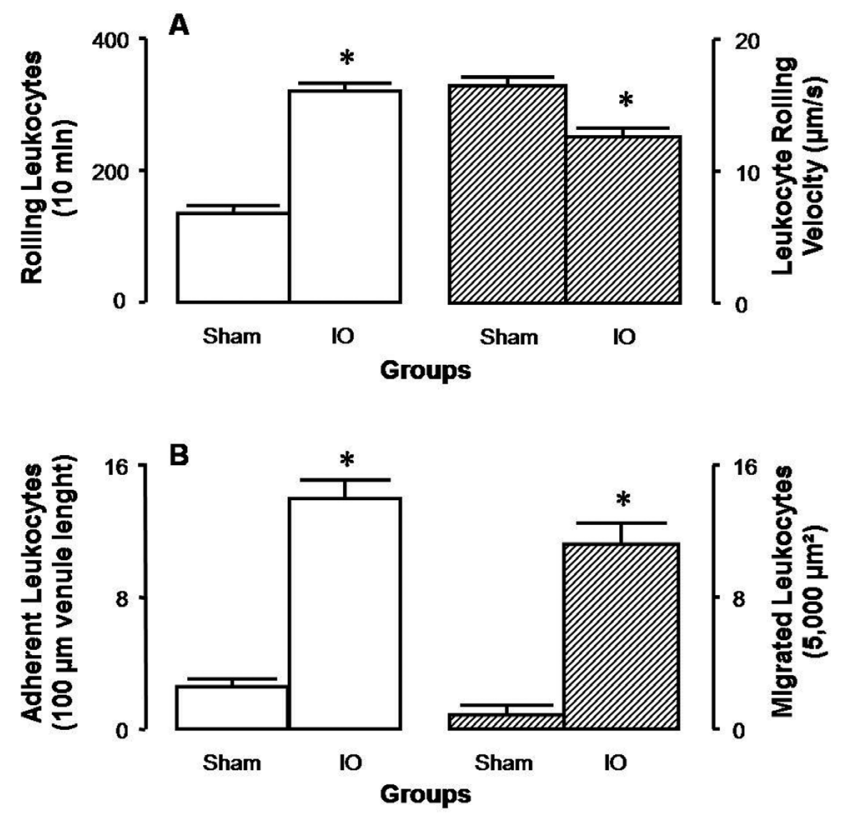

Figure 1 - Intravital microscopy of rat mesentery, $24 \mathrm{~h}$ after surgical procedures. A. Number of rolling leukocytes/10 min (open bars) and leukocyte rolling velocity $(\mu \mathrm{m} / \mathrm{s}$, hatched bars); B. number of adherent leukocytes $/ 100$ $\mu \mathrm{m}$ venule length (open bars) and number of migrated leukocytes $/ 5,000 \mu \mathrm{m}^{2}$ (hatched bars). Values are means \pm SEM for 7 rats in each group. $* P<0.001$ vs. corresponding values in Sham group a 2-fold increase in the number of rolling leukocytes, a 5 -fold increase in the number of adherent leukocytes, and an 11-fold increase in the number of migrated leukocytes (Figure 1).

\section{Expression of P-selectin and ICAM-1}

Twenty-four hours after the surgical procedures, expression of P-selectin was markedly increased in the mesenteric microvessels of IO rats compared to Sham rats, as evidenced by immune staining. Similar results were obtained for ICAM-1 expression on mesenteric microvessels. Representative sections of these preparations and the quantitative evaluation of immune staining are shown in Figure 2.

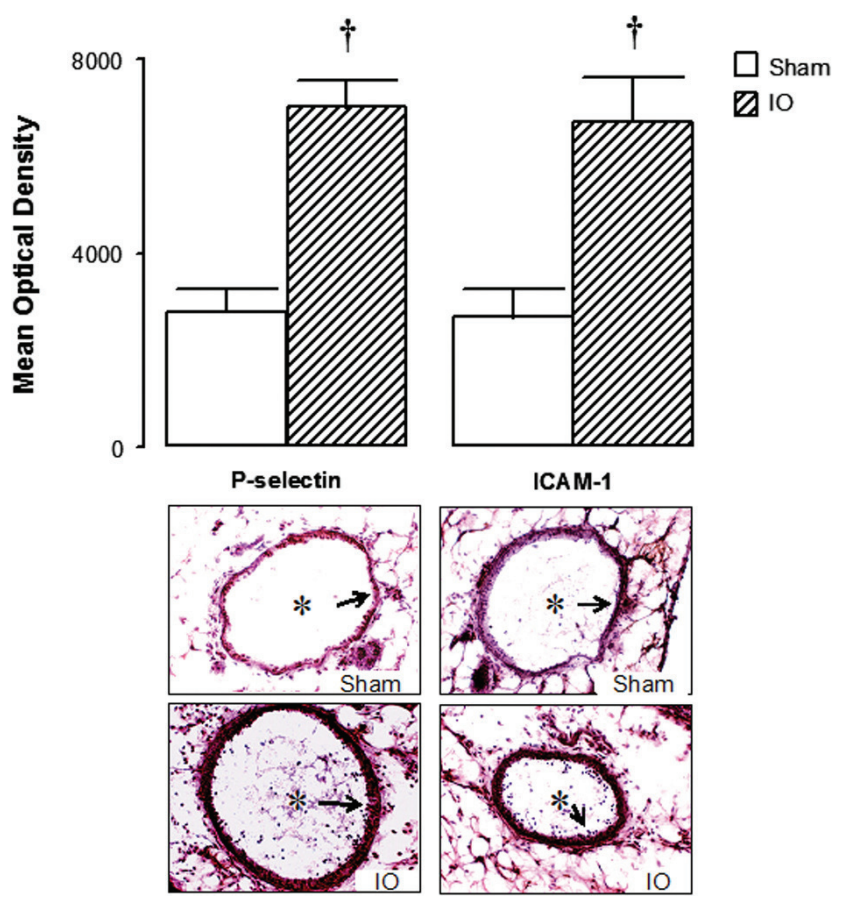

Figure 2 - Microphotographs of the mesentery and quantitative evaluation of immune staining for ICAM-1 and P-selectin on mesenteric microvessels obtained from Sham and IO rats. Mesenteric sections $(8 \mu \mathrm{m})$ were stained (arrows) for the detection of ICAM-1 and P-selectin. * indicates the vessel lumen (original magnification 1500x). Values are means \pm SEM for 8 samples/ rat, 3 rats/group. Analyses were performed with the software Image-Pro Plus, version 4.1, Media Cybernetics. ${ }^{\dagger} P<0.001$ vs. Sham group 


\section{DISCUSSION}

The current model reproduced several features observed in patients presenting mechanical small bowel obstruction. Important inflammatory events were observed in the mesenteric microcirculation, including an increased number of rolling, adherent, and migrated leukocytes accompanied by increased expression of P-selectin and ICAM-1 on mesenteric microvessels and neutrophilia. Hyperglycemia, hyperlactatemia, respiratory alkalosis, hyperkaliemia, and increased levels of urea, creatinine and AST and ALP activity reflect metabolic and acid-basic disorders and remote organ damage. In parallel, there was growth of enteric bacteria (E. coli) in samples of MLN, liver, spleen, and blood.

Experimental models, primarily in rodents, have been used to study intestinal BT phenomenon such as obstructive jaundice, ${ }^{21}$ pancreatitis,${ }^{22}$ cirrhosis, ${ }^{23}$ alterations of intestinal flora, ${ }^{24}$ thermal injury, ${ }^{25}$ intestinal ischemia-reperfusion, ${ }^{26}$ hemorrhagic shock, ${ }^{27}$ and intestinal obstruction. ${ }^{5-7,28}$ The current model of intestinal obstruction and ischemia is an uncomplicated surgical procedure that does not require special conditions (e.g., bacterial inoculum) and has several features observed in surgical patients.

As described previously, ${ }^{1}$ bacterial translocation was characterized by the growth of enteric bacteria (E. coli) in samples of MLN, liver, spleen, and blood. In a rat model of intestinal obstruction without ischemia, Çevikel et al. ${ }^{6}$ demonstrated the occurrence of BT in samples of MLN, liver, and blood in $67 \%$ of animals. In the same study, the rate of BT increased to $100 \%$ of MLN and $75 \%$ of liver samples when the rats were submitted to strangulated obstruction. Results presented in our study showed that samples of MLN, liver, and spleen were positive for $E$. coli in $86 \%$ of IO rats. Positive hemocultures were observed in $57 \%$ of IO rats. Similar rates of BT were observed in the present model. In Sham-operated rats, a positive bacterial culture was observed in only one MLN sample, but low $E$. coli $\mathrm{CFU} / \mathrm{g}$ counts were observed compared to rats submitted to intestinal obstruction and ischemia. Translocation of commensal bacteria can be considered a normal physiological phenomenon, considering that the majority of bacteria that cross the intestinal mucosa are destroyed by the gut-associated lymphoid tissue. ${ }^{29}$ Similar findings were observed in BT models beyond those using intestinal obstruction and ischemia, such as in models of intestinal bacterial inoculums, ${ }^{24}$ thermal injury, ${ }^{25}$ and obstructive jaundice. ${ }^{21} \mathrm{BT}$ has been shown to occur in healthy patients and is elevated in critically ill patients with trauma, shock, sepsis, or thermal injury. ${ }^{30}$ The main mechanisms involved in promoting BT are an alteration in indigenous gastrointestinal microflora, which results in bacterial overgrowth; physical disruption of the gut mucosal barrier by reduced blood flow to the intestine; and impairment of the host defenses. ${ }^{30}$

It has been recognized that major trauma, shock, or burn injury can lead to an MOD syndrome that is associated with a high mortality rate. Deitch et al. ${ }^{31}$ emphasize the role of the gut in the development of injury and shock-induced MOD. Indeed, sustained vasoconstriction after hemorrhagic shock, or blood flow redistribution associated with septic shock, may cause splanchnic hypoperfusion, ${ }^{32,33}$ disruption of the gut mucosal barrier, and BT. In addition, the gut and gut-associated lymphoid tissues produce cytokines and other inflammatory mediators, which may contribute to systemic inflammation and MOD. ${ }^{13,31}$ Results presented here demonstrate the translocation of bacteria to the liver accompanied by the presence of hepatic injury; this was indicated by the increased serum activity of AST and ALP and the increased levels of total bilirubin. In a rat model of endotoxemia, ${ }^{34}$ ALT and AST activities increase significantly $24 \mathrm{~h}$ after injection of LPS, reflecting the hepatic injury. In addition, significant increases in the levels of serum urea and creatinine were observed in our study, suggesting the presence of acute renal failure, a frequent remote complication after sepsis and trauma. ${ }^{35}$

In critically ill patients, hyperglycemia is a common finding and is associated with increased mortality. ${ }^{36,37}$ The exact mechanisms of this hyperglycemia are unclear, but it may result from the effects of counter-regulatory factors such as elevated levels of cortisol and cytokines. ${ }^{38}$ In a trauma animal model, control of the hyperglycemic state with insulin attenuates the pulmonary injury. ${ }^{39}$ One study found a correlation between higher blood glucose levels and an increased mortality rate in a hyperglycemic septic model..$^{40}$ In the present study, rats submitted to intestinal obstruction and ischemia presented hyperglycemia ( 200 $\mathrm{mg} / \mathrm{dL}$ ) $24 \mathrm{~h}$ after the surgical procedure. Some biomarkers (such as serum lactate) can be used as predictors of mortality in patients with infection. ${ }^{41,42}$ Rats submitted to intestinal obstruction and ischemia presented a 2-fold increase in lactate levels $(\sim 5 \mathrm{mmol} / \mathrm{L}) 24 \mathrm{~h}$ after surgery. In parallel, mortality rates increased from $58 \%$ at $48 \mathrm{~h}$ to $83 \%$ at $72 \mathrm{~h}$ following intestinal obstruction and ischemia.

Microcirculation is essential for efficient delivery of oxygen to the cells. In critically ill patients, multiple organ dysfunction is associated with microcirculatory alterations and death. ${ }^{43,44}$ The crucial role of the interactions between endothelial cells and leukocytes is further emphasized by the beneficial effects of therapeutic interventions acting at this level..$^{45}$ During an inflammatory response, leukocytes roll along the lining endothelium of post-capillary venules and eventually become firmly attached to the vascular 
wall before migrating into tissues. Specific adhesion glycoproteins expressed on the surface of leukocytes and endothelial cells play a relevant role in the accumulation of leukocytes in the inflammatory lesion. ${ }^{46,47}$ Members of the selectin family of cell adhesion molecules are thought to mediate leukocyte rolling along the walls of the microvasculature. ${ }^{46}$ Glycoproteins of the CD11/CD18 complex ( $\beta_{2}$ integrins) that are expressed on leukocytes interact with ligands such as ICAM-1 on the endothelial cells to mediate leukocyte adhesion and migration. ${ }^{47}$

Microcirculatory dysfunctions similar to those observed in humans have been shown to occur in experimental models of sepsis. ${ }^{16,48,49}$ Direct assessment of microcirculatory perfusion has been studied extensively in vivo in animals using intravital microscopy. In attempting to examine the intestinal microvasculature following a regional ischemia/ reperfusion in the mesenteric vessels in hamsters, Boyd et al..$^{50}$ observed that a greater accumulation of leukocytes occurs in the mucosa. These authors also found that the crypt layer accounted for the majority of infiltrated cells as compared with the serosal layer and the mesentery. Farquhar et al..$^{51}$ demonstrated a decrease in the number of perfused capillaries in the small bowel mucosa of rats, using intravital microscopy in a normotensive sepsis model induced by cecal ligation and puncture (CLP). In a rat model of peritonitis, Lehmann et al. ${ }^{52}$ have shown an increased number of leukocytes sticking within venules of the intestinal submucosal layer and a decrease in the functional capillary density of the intestinal wall. Compared to the current model of strangulated small bowel obstruction, the CLP model induces inflammatory disorders with similar magnitude, as demonstrated by Nakagawa et al. ${ }^{17}$ However, unlike the CLP model, the strangulated small bowel obstruction model induced translocation of indigenous bacteria without surgically induced contamination of the peritoneal cavity.

In the current study, intravital microscopy was used to observe leukocyte-endothelial interactions in the mesenteric post-capillary venules of rats submitted to intestinal obstruction and ischemia. The real-time data presented here demonstrate a reduction in leukocyte rolling velocity and significant increases in the number of rolling, adherent, and migrated leukocytes $24 \mathrm{~h}$ after injury. In parallel, the expression of P-selectin and ICAM-1 in the mesenteric microvessels of these animals was markedly increased compared to Sham-operated rats. The accumulation of leukocytes in the inflamed tissues is preceded by leukocyte rolling and adhesion to the vascular endothelium. Leukocytes roll along the walls of post-capillary venules, mediated by the selectin family of adhesion molecules. ${ }^{46}$ The interaction between ICAM-1 on the endothelial cells and $\beta_{2}$ integrins (CD11/CD18) on the leukocytes allows the leukocytes to become firmly adherent to the vascular wall. ${ }^{47}$ The crucial role of adhesion molecules in leukocyte recruitment has been further emphasized by studies carried out on P-selectin-deficient mice ${ }^{53}$ and ICAM-1-deficient mice, ${ }^{54}$ both of which exhibit impaired neutrophil migration in response to noxious stimuli. The upregulation of P-selectin and ICAM-1 on mesenteric microvessels after intestinal obstruction and ischemia, as demonstrated in this study, suggests that generalized endothelial cell activation and the associated inflammatory response might precede the phenomenon of BT and MOD. Samel et al. ${ }^{28}$ used intravital microscopy to assess the translocation of inoculated viable fluorescent $E$. coli under conditions of intestinal obstruction and ischemia in rats. This study demonstrated that the segmental ischemia of the obstructed small bowel accelerates translocation of bacteria into the submucosa and muscularis propria and further translocation to extraintestinal organs such as the liver and spleen. In this study ${ }^{28}$, green fluorescent protein-transfected $E$. coli were visible in the submucosa and muscularis 10 and 60 min after E. coli administration, respectively. In the present study, bacterial translocation was evaluated $24 \mathrm{~h}$ after intestinal obstruction and ischemia, as previously demonstrated. ${ }^{5-7}$

Intestinal obstruction and ischemia in rats is a relevant model for the in vivo study of mesenteric microcirculatory dysfunction and the occurrence of bacterial translocation and parallels the events implicated in MOD and death.

\section{ACKNOWLEDGMENTS}

This work was supported by Fundação de Amparo à Pesquisa do Estado de São Paulo 04/15964-6 and Pronex/ CNPq 66.11251998-2, Brazil.

\section{REFERENCES}

1. Berg RD, Garlington AW. Translocation of certain indigenous bacteria from the gastrointestinal tract to the mesenteric lymph nodes and other organs in a gnotobiotic mouse model. Infect Immun 1979;23:403-11.
2. MacFie J, O'Boyle C, Mitchell CJ, Buckley PM, Johnstone D, Sudworth $\mathrm{P}$. Gut origin of sepsis: a prospective study investigating associations between bacterial translocation, gastric microflora, and septic morbidity. Gut. 1999;45:223-8. 
3. Overhaus M, Tögel S, Pezzone MA, Bauer AJ. Mechanisms of polymicrobial sepsis-induced ileus. Am J Physiol Gastrointest Liver Physiol 2004;287:G685-94.

4. Menchaca-Diaz JL, Silva RM, Siqueira AFRS, Ruiz-Silva M, Buzzutti FI, Siliano PR, et al. Changes in Bacterial Translocation Profile Induced by Sepsis. Transplant Proc. 2002;34:1007-8.

5. Antequera R, Bretana A, Cirac A, Brito A, Romera MA, Zapata R. Disruption of the intestinal barrier and bacterial translocation in an experimental model of intestinal obstruction. Acta Científica Venezoelana. 2000;51:18-26.

6. Cevikel MH, Ozgun H, Boylu S, Demirkiran AE, Aydin N, Sari C, et al. C-reactive protein may be a marker of bacterial translocation in experimental intestinal obstruction. ANZ J Surg. 2004;74:900-4.

7. Oliveira MA, Lemos DS, Diniz SO, Coelho JV, Cardoso VN Prevention of bacterial translocation using glutamine: a new strategy of investigation. Nutrition. 2006;22:419-24.

8. Lozano FS, Cascajo C, García-Sánchez E, Barros MB, García-Criado FJ, Parreño F, et al. Bacterial translocation as a source of Dracon-graft contamination in experimental aortic operation: the importance of controlling SIRS. Surgery. 2006;140:83-92.

9. MacFie J, Reddy BS, Gatt M, Jain PK, Sowdi R, Mitchell CJ. Bacterial translocation studied in 927 patients over 13 years. Br J Surg. 2006;93:87-93.

10. O'Boyle CJ, MacFie J, Mitchell CJ, Johnstone D, Sagar PM, Sedman PC Microbiology of bacterial translocation in humans. Gut. 1998;42:29-35.

11. Reddy BS, MacFie J, Gatt M, Macfarlane-Smith L, Bitzopoulou K, Snelling AM. Commensal bacteria do translocate across the intestinal barrier in surgical patients. Clin Nutr. 2007;26:208-15.

12. Shiomi H, Shimizu T, Endo Y, Murata S, Kurumi Y, Uji Y, et al. Relations among circulating monocytes, dendritic cells, and bacterial translocation in patients with intestinal obstruction. World J Surg. 2007;31:1806-12.

13. Deitch EA. Bacterial translocation or lymphatic drainage of toxic products from the gut: what is important in human beings? Surgery. 2002;131:241-4.

14. Balzan S, de Almeida Quadros C, de Cleva R, Zilberstein B, Cecconello I. Bacterial translocation: overview of mechanisms and clinical impact. J Gastroenterol Hepatol. 2007;22:464-71.

15. Hayanga AJ, Bass-Wilkins K, Bulkley GB. Current management of small-bowel obstruction. Adv Surg. 2005;39:1-33.

16. Nakagawa NK, Nogueira RA, Correia CJ, Shiwa SR, Costa Cruz JW, Poli de Figueiredo LF, et al. Leukocyte-endothelium interactions after hemorrhagic shock/reperfusion and cecal ligation/puncture: an intravital microscopic study in rat mesentery. Shock. 2006;26:180-6.

17. Nakagawa NK, Jukemura J, Aikawa P, Nogueira RA, Poli de Figueiredo LF, Sannomiya P. In vivo observation of mesenteric leukocyteendothelial interactions after cecal ligation/puncture and surgical sepsis source control. Clinics. 2007;62:321-6.

18. Kubes P, Heit B, van Marle G, Johnston JB, Knight D, Khan A, et al. In vivo impairment of neutrophil recruitment during lentivirus infection. J Immunol. 2003;171:4801-8.

19. Xie X, Hedoqvist P, Lindbom L. Influence of local haemodynamics on leukocyte rolling and chemoattractant-induced firm adhesion in microvessels of the rat mesentery. Acta Physiol Scand. 1999;165:251-8.
20. Yada-Langui MM, Anjos-Valotta EA, Sannomiya P, Rocha e Silva M, Coimbra R. Resuscitation affects microcirculatory polymorphonuclear leukocytes behavior after hemorrhagic shock: role of hypertonic saline and pentoxifylline. Exp Biol Med. 2004;229:684-93.

21. Deitch EA, Sittig K, Li M, Berg R, Specian RD. Obstructive jaundice promotes bacterial translocation from the gut. Am J Surg. 1990;159:7984.

22. van Minnen LP, Timmerman HM, Lutgendorff F, Verheem A, Harmsen W, Konstantinov SR, et al. Modification of intestinal flora with multispecies probiotics reduces bacterial translocation and improves clinical course in a rat model of acute pancreatitis. Surgery. 2007;141:470-80

23. Wiest R, Garcia-Tsao G. Bacterial translocation (BT) in cirrhosis Hepatology. 2005;41:422-33.

24. Koh IH, Menchaca-Diaz JL, Farsky SHP, Siqueira AFRS, Ruiz-Silva $\mathrm{M}$, Juliana P, et al. Injuries to the Mesenteric Microcirculation Due to Bacterial Translocation. Transplant Proc. 2002;34:1003-4.

25. Gun F, Salman T, Gurler N, Olgac V. Effect of probiotic supplementation on bacterial translocation in thermal injury. Surg Today. 2005;35:760-4.

26. Moore-Olufemi SD, Kozar RA, Moore FA, Sato N, Hassoun HT, Cox CS $\mathrm{Jr}$, et al. Ischemic preconditioning protects against gut dysfunction and mucosal injury after ischemia/reperfusion injury. Shock. 2005;23:25863.

27. Hirsh M, Dyugovskaya L, Bashenko Y, Krausz MM. Reduced rate of bacterial translocation and improved variables of natural killer cell and T-cell activity in rats surviving controlled hemorrhagic shock and treated with hypertonic saline. Crit Care Med. 2002;30:861-7.

28. Samel S, Keese M, Kleczka M, Lanig S, Gretz N, Hafner M, et al. Microscopy of bacterial translocation during small bowel obstruction and ischemia in vivo--a new animal model. BMC Surg. 2002;2:6.

29. Baumgart DC, Dignass AU. Intestinal Barrier Function. Curr Opin Clin Nutr Metab Care. 2002;5:685-94.

30. Madl C, Druml W. Gastrointestinal disorders of the critically ill. Systemic consequences of ileus. Best Pract Res Clin Gastroenterol. 2003; 17:445-56

31. Deitch EA, Xu D, Kaise VL. Role of the gut in the development of injury-and shock induced SIRS and MODS: the gut-lymph hypothesis, a review. Front Biosci. 2006;11:520-8.

32. Lagoa CE, Poli de Figueiredo LF, Cruz Jr RJ, Silva E, Rocha e Silva M. Effects of volume resuscitation on splanchnic perfusion in canine model of severe sepsis induced by live Escherichia coli infusion. Crit Care. 2004;8:R221-8

33. Garrido AG, Poli de Figueiredo LF, Cruz Jr RJ, Silva E, Rocha e Silva M. Short-lasting systemic and regional benefits of early crystalloid infusion after intravenous inoculation of dogs with live Escherichia coli. Braz J Med Biol Res. 2005;38:873-84.

34. Jeschke MG, Rensing H, Klein D, Schubert T, Mautes AE, Bolder $\mathrm{U}$, et al. Insulin prevents liver damage and preserves liver function in lipopolysaccharide-induced endotoxemic rats. J Hepatol. 2005;42:870-9.

35. Anderson RJ. Kidney in sepsis. Crit Care Med. 2007;35:2223-4.

36. Van den Berghe G, Wouters P, Weekers F, Verwaest C, Bruyninckx F, Schetz M, et al. Intensive insulin therapy in critically ill patients. N Engl J Med. 2001;345:1359-67. 
37. Henderson WR, Chittock DR, Dhingra VK, Ronco JJ. Hyperglycemia in acutely ill emergency patients--cause or effect? CJEM. 2006;8:339-43.

38. Falciglia M. Causes and consequences of hyperglycaemia in critical illness. Curr Opin Clin Nutr Metab Care. 2007;10:498-503.

39. Donnelly M, Condron C, Murray P, Bouchier-Hayes D. Modulation of the glycemic response using insulin attenuates the pulmonary response in an animal trauma model. J Trauma. 2007;63:351-7.

40. Heuer JG, Sharma GR, Zhang T, Ding C, Bailey DL, Stephens EJ, et al. Effects of hyperglycemia and insulin therapy on outcome in a hyperglycemic septic model of critical illness. J Trauma. 2006;60:86572 .

41. Shapiro NI, Howell MD, Talmor D, Nathanson LA, Lisbon A, Wolfe RE, et al. Serum lactate as a predictor of mortality in emergency department patients with infection. Ann Emerg Med. 2005;45:524-8.

42. Trzeciak S, Dellinger RP, Chansky ME, Arnold RC, Schorr C, Milkarek $\mathrm{B}$, et al. Serum lactate as a predictor of mortality in patients with infection. Intensive Care Med. 2007;33:970-7.

43. De Backer D, Creteur J, Preiser J-C, Dubois M-J, Vincent JL: Microvascular blood flow is altered in patients with sepsis. Am J Respir Crit Care Med. 2002;166:98-104.

44. Sakr Y, Dubois MJ, De Backer D, Creteur J, Vincent JL. Persistent microcirculatory alterations are associated with organ failure death in patients with septic shock. Crit Care Med. 2004;32:1825-31.

45. Hotchkiss RS, Karl IE. The pathophysiology and treatment of sepsis. N Engl J Med. 2003;348:138-50.
46. Rosen SD. Ligands for L-selectin: Homing, inflammation, and beyond. Annu Rev Immunol. 2004;22:129-56.

47. Mayadas TN, Cullere X. Neutrophil beta2 integrins: moderators of life or death decisions. Trends Immunol. 2005;26:388-95.

48. Schmidt H, Secchi A, Wellmann R, Bach A, Böhrer H, Gebhard MM, et al. Effect of endotoxemia on intestinal villus microcircularion in rats. J Surg Res. 1996;61:521-26.

49. Smalley DM, Childs EW, Cheung LY. The local effect of PAF on leukocyte adherence to small bowel mesenteric venules following intraabdominal contamination. Inflammation. 2000;24:399-410.

50. Boyd AJ, Sherman IA, Saibil FG. Intestinal microcirculation and leukocyte behavior in ischemia-reperfusion injury. Microvasc Res. 1994;47:355-68.

51. Farquhar I, Martin CM, Lam C, Potter R, Ellis, CG, Sibbald WJ. Decreased capillary density in vivo in bowel mucosa of rats with normotensive sepsis. J Surg Res. 1996;61:190-6.

52. Lehmann C, Bac VH, Pavlovic D, Lustig M, Maier S, Feyerherd F, et al. Metronidazole improves intestinal microcirculation in septic rats independently of bacterial burden. Clin Hemorheol Microcirc. 2006;34:427-38.

53. Mayadas TN, Johnson RC, Rayburn H, Hynes RO, Wagner DD. Leukocyte rolling and extravasation are severely compromised in P-selectin deficient mice. Cell. 1993;74:541-54.

54. Sligh JE Jr, Ballantyne CM, Rich SS, Hawkins HK, Smith CW, Bradley $\mathrm{A}$, et al. Inflammatory and immune responses are impaired in mice deficient in intercellular adhesion molecule 1. Proc Natl Acad Sci USA. 1993;90:8529-33. 
